\title{
Assessment of Hemoglobin Level in Relation to Dietary Habits among Adolescent Girls
}

\author{
Tahira Bibi', Nazia Yousef2, Neelam Zia³ ${ }^{3}$ Uzma Tariq ${ }^{4}$ \\ 1Department of Nursing, College of Nursing, Shahdra Hospital, Lahore-Pakistan, 2,4Department of Research, Superior University Lahore-Pakistan, ${ }^{3}$ Department of Nursing, Sir Ganga \\ Ram Hospital, Lahore-Pakistan
}

\section{ABSTRACT}

Background: Adolescence is considered as a period of increased demand of physiological needs including macro and micro nutrients. The requirement of some minerals as such iron and zinc are of top important elements involved in the physical and mental growth and development of adolescents. Low intake of iron rich food and excessive blood loss in menstruation are main reasons of iron deficiency anaemia in adolescent girls. Objective: a) To calculate the haemoglobin $\mathrm{Hb}$ level of adolescent girls in relation to their dietary habits. b) To compare $\mathrm{Hb}$ level in early and late adolescent girls. Study Design: Cross-sectional descriptive study. Settings: Three schools and two colleges of Shahdara region Lahore Pakistan. Duration: Six months from April to October 2017. Methodology: Cross-sectional descriptive study in which 262 adolescent girls were selected by stratified random sampling. The data was collected through food frequency questionnaire. Chi square test was used to find the association between food intake frequency and $\mathrm{Hb}$ level. Results: From sample of 262 adolescents $31.2 \%$ girls have BMI less than $5^{\mathrm{TH}}$ percentile and $27.6 \%$ were found obese.31.2 adolescents were found anemic. Association was found between $\mathrm{Hb}$ level and intake of meat, beef, beef liver, legumes, nuts, black beans, dark chocolates, green vegetables, fruits, chapatti and iron supplements. Conclusion: The results identified the decrease intake of potential nutrients, low level of income, less education level of mothers and large number of family contributing to anemia in adolescent girls.

Keywords: Adolescent, Iron deficiency anaemia, Haemoglobin level, Nutritional status.

Corresponding Author

Submitted for Publication: 11-03-2020

Accepted for Publication: 19-09-2020

Tahira Bibi, Assistant Nursing Instructure, Department of Nursing, College of Nursing, Shahdra Hospital, Lahore-Pakistan.

Email: tahira.rehmat@yahoo.com

Citation: Bibi T, Yousef N, Zia N, Tariq U. Assessment of Hemoglobin Level in Relation to Dietary Habits Among Adolescent Girls. APMC 2020;14(3):240-4.

\section{DOI: $10.29054 / A P M C / 2020.877$}

\section{INTRODUCTION}

Although all stages of life cycle require healthy nutrition but adolescence is considered as a period of increased demand of physiological needs including macro and micro nutrients because this is the period of growth and development. ${ }^{1}$ Many changes occur in life style of adolescents in this period. These Changes in lifestyle may affect their eating habits and food choices. However international research has reported unhealthy food habits in adolescents, such as consumption of soft drinks, fried foods and fast food that may have bad effect on their health. The non-inclusion of fruits and vegetables in their diet is also found that lead to nutritional inadequacy, and particularly micronutrient deficiencies, in adolescents. ${ }^{2}$

Among adolescents, girls are found exposed group especially in developing countries like Pakistan. Customarily they face discrimination at every stage of life. Due to these discriminations they have minimal intake of micro and macro nutrients that Increases the risk of nutritional deficiencies in adolescent girls and they are considered as nutritionally weak part of population. Along with nutritional discrimination they are also married at a premature age and are at greater risk for reproductive morbidity and mortality. ${ }^{3}$

The requirement of some minerals as iron and zinc are of top important elements involved in the physical and mental growth of adolescents. Low intake of iron rich food and excessive blood loss in menstruation are main reasons of iron deficiency anemia in adolescent girls. ${ }^{4}$

It is estimated that prevalence of anemia among adolescents is found $27 \%$ in developing countries, and $6 \%$ in developed countries. ${ }^{5}$ In Pakistan $50 \%$ of the females of reproductive age suffer from iron deficiency anemia while in the urban Punjab $21.8 \%$ of the females aged $9-29$ are having mild to severe anemia. $^{6}$

The prevalence of anemia is inexplicably high in under developed countries because of poverty, inadequate weight loss program, certain diseases, pregnancy/lactation and improper health services with a multitude of social customs and beliefs cited against women. ${ }^{7}$

Anemia is one major factor that affects the health of adolescence. Girls who are suffering from this problem are unable to solve all emotional, behavioral and academic problems effectively. ${ }^{8}$ The world's adolescent population is going through a chain of serious nutritional demanding situations which are not only affecting their growth and development however additionally their livelihood as adults. So, the status of hemoglobin level in adolescent girls in relation to their dietary habits is assessed in this study.

\section{METHODOLOGY}

Study Design: Cross-sectional descriptive study. 
Settings: Three schools and two colleges of Shahdara region Lahore Pakistan.

Duration: Six months from April to October 2017.

Sample Technique: Stratified random sampling.

Data Collection Procedure: This study considered the adolescent girls of age 12-19 years from schools and colleges of Shahdara region. It includes female students of the 8 th-13th standards from three major girl's high schools and two colleges of Shahdara region. Permission for data collection has taken from district education officer Lahore for schools and director of public instruction (colleges) Punjab Lahore for colleges. The student's list was taken from the administration of the girl's schools and colleges.

After taking consent from study participants strata of each class were made ( 6 strata) and data was collected by stratified random sampling. As the sample size was 262 girls from three schools and two colleges so equal number 43 or 44 of students were selected from each stratum so that each age group can be represented equally.

Subjects were divided into two groups as early and late adolescents. Students from class grade $8^{\text {th }}$ to $10^{\text {th }}$ were considered early adolescents and students from the class $11^{\text {th }}$ to $13^{\text {th }}$ grades were considered late adolescents to make comparison between both groups for their $\mathrm{Hb}$ level. Data was collected by food frequency questionnaire that comprise four parts personal information, assessment of hemoglobin level, assessment of BMI and frequency of food intake. Blood samples were collected by expert technician and were analyzed for $\mathrm{Hb}$ level on X2 machine from Govt teaching hospital Shahdara Lahore. Data collection was completed in three months. After collection data was analyzed by SPSS version 20. Descriptive statistics-percentages and frequencies were used to analyse the data and chi2 was used to assess association between eating habits and $\mathrm{Hb}$ level of adolescents.

\section{RESULTS}

As shown in table no 1 all subjects were female adolescent from $8^{\text {th }}$ to $13^{\text {th }}$ class grades between the ages of 12-19 years. Subjects were selected equally from both groups as 131 from early adolescents and 131 from late adolescent group. From $(\mathrm{N}=262) 44$ or 43 subjects were selected from each stratum. Most of student's father do private job (37.7\%) and other students' father did govt job (36.6\%) and (25.5\%) girl's fathers were labourer. A very large numbers of father's income was 25000 to $35000(82.07 \%)$ and very few have 15000 to $20000(17.93 \%)$. This showed that most of girls belong to poor and middle-class families.

From $(n=262) 31.2 \%$ subjects were found under weight as their BMI fall below the $5^{\text {th }}$ percentile, $41.2 \%$ have normal BMI and $27.6 \%$ were found overweight. As shown in table No 1, 65.1\% adolescents have normal $\mathrm{Hb}$ level, only $3.4 \%$ adolescents have healthy $\mathrm{Hb}$ level as $12.4-14 \mathrm{mg} / \mathrm{dl}$. $31.2 \%$ subjects were found anemic as their $\mathrm{Hb}$ level range from $11-11.9 \mathrm{mg} / \mathrm{dl}$ and this is an alarming rate of anemia in Shahdra region.
Table No 1: Demographic variables

\begin{tabular}{|c|c|c|}
\hline Variables & Frequency distribution \& \% & $P$ value \\
\hline \multicolumn{3}{|l|}{ Age $n, \%$} \\
\hline $12-15$ years & $131(50)$ & \multirow{2}{*}{0.481} \\
\hline $16-19$ years & $131(50)$ & \\
\hline \multicolumn{3}{|l|}{ Class grade $n, \%$} \\
\hline $8^{\text {th }}$ grade- $10^{\text {th }}$ grade & $132(50.1)$ & \multirow[b]{2}{*}{0.649} \\
\hline $\begin{array}{l}11^{\text {th }} \text { grade }-13^{\text {th }} \\
\text { grade }\end{array}$ & $130(49.9)$ & \\
\hline \multicolumn{3}{|c|}{ Father occupation $\mathrm{n}, \%$} \\
\hline Govt job & $96(36.6)$ & \multirow{3}{*}{$0.000^{* *}$} \\
\hline Private job & $99(37.7)$ & \\
\hline Labourer & $67(25.5)$ & \\
\hline \multicolumn{3}{|l|}{ Father income n, \% } \\
\hline $15000-25000$ & $47(17.93)$ & \multirow{2}{*}{$0.000^{* *}$} \\
\hline $25000-35000$ & $215(82.07)$ & \\
\hline \multicolumn{3}{|l|}{ BMI n, \% } \\
\hline$<5^{\text {th }}$ percentile & $82(31.2)$ & \multirow{3}{*}{0.053} \\
\hline $5^{\text {th }}-85^{\text {th }}$ percentile & $104(41.2)$ & \\
\hline$>85^{\text {th }}$ percentile & $76(27.6)$ & \\
\hline \multicolumn{3}{|l|}{$\mathrm{Hb} \mathrm{n,} \mathrm{\%}$} \\
\hline Anaemic & $82(31.2)$ & \\
\hline Normal & $171(65.1)$ & \\
\hline Above normal & 09 (3.4) & \\
\hline
\end{tabular}

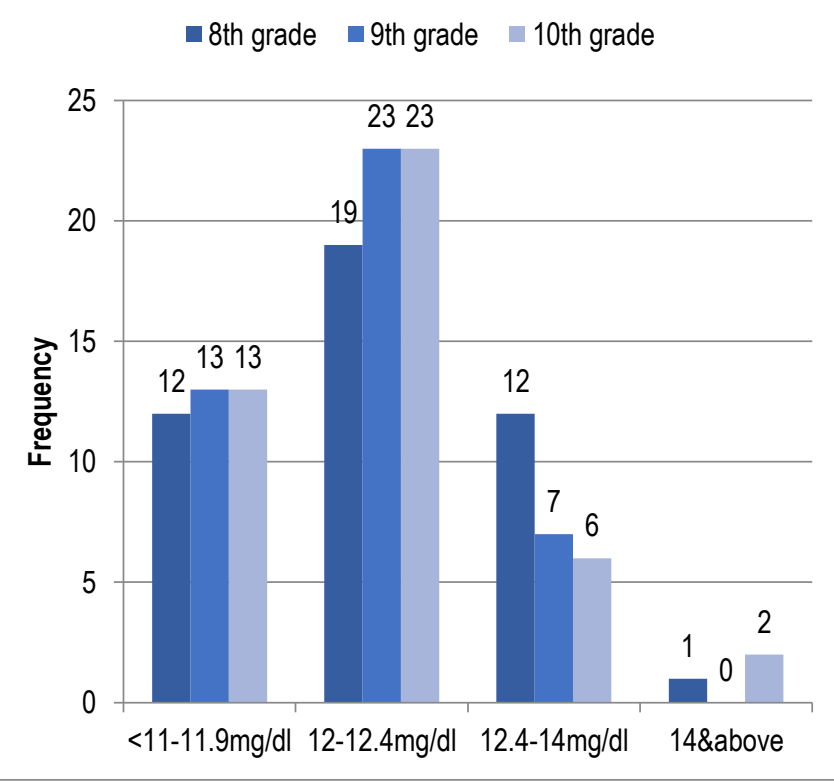

Figure 1: HB level of early adolescent girls 


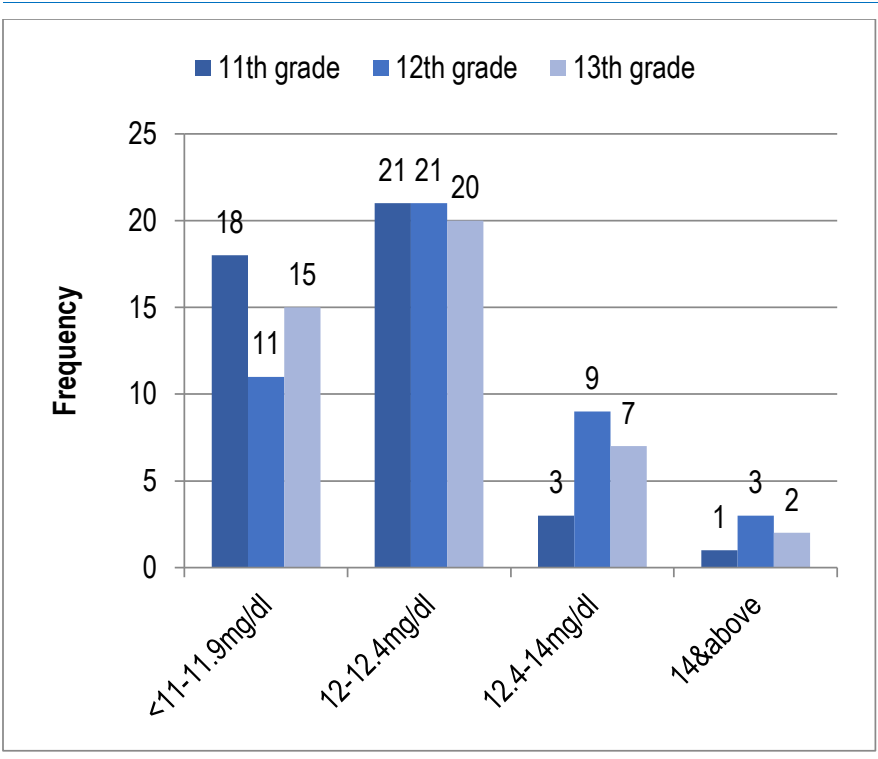

Figure 2: HB level of late adolescent girls

Upon making comparison of early and late adolescents, late adolescents were found more anemic as shown in figure no 2 late adolescent $(n=131) 33.5 \%$ and $(n=131) \quad 29 \%$ early adolescent were found Anemic. Along other contributory factors of anemia this rate showed the poor dietary habits of late adolescents.

Table 2: Meal pattern of study participants

\begin{tabular}{|l|c|c|c|c|}
\hline \multirow{2}{*}{ Meal pattern } & Always & Some time & Often & Never \\
\cline { 2 - 5 } & $\%$ & $\%$ & $\%$ & $\%$ \\
\hline Breakfast & 21.4 & 26.7 & 19.5 & 32.4 \\
\hline Mid - Morning & 26.0 & 28.2 & 21.8 & 24.0 \\
\hline Lunch & 48.1 & 35.1 & 12.2 & 4.6 \\
\hline Evening Time & 17.9 & 23.7 & 28.2 & 30.2 \\
\hline Dinner & 73.8 & 22.4 & 3.0 & 0.4 \\
\hline
\end{tabular}

This study also revealed that the girls who have taken their meal regularly were found healthy and the girls who miss their meal were found anaemic. it was investigated in this study that most of girls $32.4 \%$ have missed their breakfast and they go to their school and colleges without taking breakfast.24\% girls have never taken any food at mid-morning on the other hand large number of girls have taken their lunch and dinner and this percentage was found 48.1 and $73.8 \%$ respectively as shown in table No 2.

Association between different food items and $\mathrm{Hb}$ level was analyzed by using chi square and the results indicate that. From the group of meat, poultry and nuts great association was found between beef, beef liver and $\mathrm{Hb}$ level as their significance level was found 0.001 and 0.000 respectively. Nuts and black beans were also found significant as shown in table No 3 that their $P$ value is less than 0.05 . from the group of milk and milk products only dark chocolate was found associated with $\mathrm{Hb}$ level as its $\mathrm{P}$

value was 0.003 . from the group of vegetables and fruits green vegetables, fruits, fruit chaat and fruit juice were found significant with $\mathrm{Hb}$ level as their $\mathrm{P}$ Value was found $0.003,0.003$, 0.001 and 0.001 that is less than 0.05 .From the group of cereals only chapatti was found associated with $\mathrm{Hb}$ level as its $\mathrm{P}$ value was found 0.042 and only honey and iron supplements were fund associated with $\mathrm{Hb}$ level. The girls who have taken these food items that are associated with $\mathrm{Hb}$ level have good $\mathrm{Hb}$ level. For demographic variables data was collected by demographic portion of questionnaire. Socioeconomic status that includes father occupation, father income and number of family members were found highly associated with $\mathrm{Hb}$ level as their $\mathrm{p}$ value was less than 0.05 .

Table 3: Association between $\mathrm{Hb}$ level and food

\begin{tabular}{|l|l|l|}
\hline Variables & \multicolumn{1}{|c|}{$\chi^{2}$} & P value \\
\hline Meal pattern & & \\
\hline Break fast & 24.759 & $0.003^{* *}$ \\
\hline Mid-morning & 18.568 & $0.029^{*}$ \\
\hline Lunch & 28.284 & $0.001^{* *}$ \\
\hline Evening & 8.625 & 0.473 \\
\hline Dinner & 19.897 & $0.003^{* *}$ \\
\hline Use of milk and milk products & & \\
\hline Dark Chocolates & 38.491 & $0.003^{*}$ \\
\hline Use of Meat and beans & & \\
\hline Meat & 37.701 & $0.004^{* *}$ \\
\hline Beef & 42.314 & $0.001^{* *}$ \\
\hline Beef Liver & 76.066 & $0.000^{* *}$ \\
\hline Legumes & 29.336 & $0.044^{*}$ \\
\hline Black Beans & 34.394 & $0.011^{*}$ \\
\hline Black Grams & 30.661 & $0.031^{*}$ \\
\hline Nuts & 37.968 & $0.004^{* *}$ \\
\hline Use of vegetable & & \\
\hline Green vegetables & 39.410 & $0.003^{* *}$ \\
\hline Starchy Potato & 29.121 & $0.047^{*}$ \\
\hline Use of fruits & & \\
\hline Fruits & 38.597 & $0.003^{* *}$ \\
\hline Fruit chat & 41.168 & $0.001^{* *}$ \\
\hline Fruit Juice & 42.314 & $0.001^{* *}$ \\
\hline Use of cereals & & \\
\hline Chapati & 21.634 & $0.042^{*}$ \\
\hline Use of fats, oils and oils sweats & & \\
\hline Honey & 21.295 & $0.046^{*}$ \\
\hline Others & & \\
\hline Iron Supplement & $0.011^{*}$ \\
\hline *-value <0.05 & & \\
\hline
\end{tabular}




\section{DISCUSSION}

This study was conducted to assess the Hemoglobin level in relation to dietary habits and nutritional deficiencies in adolescent girls like iron deficiency anemia. In this study, no association was found between age and $\mathrm{Hb}$ level as $\mathrm{P}$-value was 0.481 that is more than the significance level of 0.05 that oppose the results of a previous study that reported the linear relationship between age and $\mathrm{Hb}$ level. ${ }^{9}$ However, socioeconomic status is considered as a symbol of health and it has great impact on health of all age groups particularly adolescents. This study in line with the results of prior studies that showed strong relationship between $\mathrm{Hb}$ level and socioeconomic status. ${ }^{10}$

On the other hand, the results of this study indicated a strong association between $\mathrm{BMI}$ and $\mathrm{Hb}$ level. The outcome of a study ${ }^{11}$ also evident that $\mathrm{BMI}$ is the indicator of health so the girls who have normal BMI have good $\mathrm{Hb}$ level but the upshot of another study is contradicting the results of current study. ${ }^{12}$ The result of present study are in congruence with a previous study indicate that those girls who miss their breakfast as well as not taking their meals properly have low $\mathrm{Hb}$ level. ${ }^{13}$ The findings of this study are comparable with the result of a study that signifies meat is an essential food item for growth and development of body and mind as it is rich source of iron. ${ }^{12}$ Strong association was found between meat $(p$-value $=0.004)$, beef $(p$-value $=$ 0.001 ) and beef liver $(p$-value $=0.000)$ and $\mathrm{Hb}$ level. Legumes, black beans and nuts intake also has a great impact of $\mathrm{Hb}$ level. In contrast, the results of this study are dissimilar with a study that showed significant relationship of fish, chicken and eggs with $\mathrm{Hb}$ level. ${ }^{14}$ Findings of this study compatible with the findings of another study that intake of milk and milk products was not inhibit the absorption of iron. Although, a significant association was found between reduced level of $\mathrm{Hb}$ and in dark chocolate intake. ${ }^{15}$ Moreover, the current study shows similar results with another study that green vegetables, starchy potatoes, fruits and fruits containing food items are better to improve hemoglobin level. ${ }^{10}$

Furthermore, the results of present study are also aligned with another that showed no noteworthy relationship between cereals group and $\mathrm{Hb}$ level. ${ }^{2}$ The findings of this study are similar with the result of a study, revealed that fast-food and beverages are getting in vogue among adolescents. However, these are not good for the health of adolescents as this food stuff reduces the iron binding capacity that leads to low level of $\mathrm{Hb} .{ }^{13}$

It is evident that good dietary habits and proper nutritional intake are essential to maintain an adequate $\mathrm{Hb}$ level in adolescent girls. Consequently, it can helpful to reduce the morbidity and mortality rate among these girls as they are the future mothers.

\section{CONCLUSION}

This study highlights that adolescent girls are at a greater risk for anemia. Severity of anemia was found to be gradually increased from early to late adolescent group. The results identified the decrease intake of potential nutrients, low level of income, less education level of mothers and large number of family contributing to anemia in adolescent girls.

\section{SUGGESTIONS / RECOMMENDATIONS}

In order to decrease prevalence of anemia, government should start health education programs in school and college level which will further help the students to adopt healthy eating pattern and selection of healthy food.

\section{CONFLICT OF INTEREST / DISCLOSURE}

The authors have no conflicts of interest in this work.

\section{ACKNOWLEDGEMENTS}

I would like to thank Madam Gulshad Naseem (District education officer) providing the great help to collect data from different schools and colleges of Shahdra region.

\section{REFERENCES}

1. Jawed S, Tariq S, Tariq S, Kamal A. Frequency of nutritional anemia among female medical students of Faisalabad. Pak J Med Sci. 2017;33(2):398-403.

2. Azemati B, Khoramdad M, Qorbani M, Rastad H, Shafiee G, Heshmat R, Kelishadi R. Percentile values of serum zinc concentration and prevalence of its deficiency in Iranian children and adolescents: the CASPIAN-V study. J Pediatr Endocrinol Metab. 2020;33(4):525-31.

3. Patil S, Joglekar C, Desai M, Yadav A, Sonawane S, Chavan R, Mohite R. Nutritional Status and Psychological Impairment in Rural Adolescent Girls: Pilot Data From "KOKAN" Region of Western India. Front Public Health. 2018;6:160.

4. Biletska E, Shtepa O, Kalinicheva V, Valchuk SJMp. Study of modification of zinc status of laboratory animals in conditions of low-dose action of lead and zinc in various forms. Medical Perspective. 2017;22(4):13-9.

5. Habib MA, Raynes-Greenow C, Soofi SB, Ali N, Nausheen S, Ahmed I, Bhutta ZA, Black Kl. Prevalence and determinants of iron deficiency anemia among non-pregnant women of reproductive age in Pakistan. Asia Pac J Clin Nutr. 2018;27(1):195-203.

6. Khatoon S, Ahmed A, Yousaf S. Iron Deficiency Anaemia In Pakistan: Celiac Disease an Underlying Cause. J Ayub Med Coll Abbottabad. 2018;30(3):372-6.

7. Akhtar S. Malnutrition in South Asia-A Critical Reappraisal. Crit Rev Food Sci Nutr. 2016;56(14):2320-30.

8. Gonete KA, Tariku A, Wami SD, Derso TJAoPH. Prevalence and associated factors of anemia among adolescent girls attending high schools in Dembia District, Northwest Ethiopia, 2017. BMC. 2018;76(1):79.

9. Anisa N, Wahyuni S, Rahayu S, Choirunnisa A, Martanti LE, editors. Effect of Moringa Leaves and Vitamin C Capsule Combinations in Increaseing Hemoglobin Levels of Young Women with Anemia. Proceedings of the International Conference on Applied Science and Health; 2019.

10. Chand MIA, Nandan M, Mukherjee BJJoEoM, Sciences D. A study of prevalence of anaemia and sociodemographic factors associated with anaemia among adolescent girls in rural area of Katihar, Bihar. J Evolution Med Dental Sci. 2016;5(74):5470-4.

11. Teni M, Shiferaw S, Asefa FJB, Sciences $H$. Anemia and its relationship with academic performance among adolescent 
school girls in Kebena District, Southwest Ethiopia. Biotech Health Sci. 2017;4(1):e43458.

12. Jalambo M, Karim N, Naser I, Sharif RJEMHJ. Effects of iron supplementation and nutrition education on hemoglobin, ferritin and oxidative stress in iron-deficient female adolescents in Palestine: randomized control trial. East Mediterr Health $\mathrm{J}$. 2018;24(6):560-8.

13. Khapre M, Shewade HD, Kishore S, Ramaswamy G, Dongre ARJJoFM, Care P. Understanding barriers in implementation and scaling up WIFS from providers perspective: A mixed-method study, Rishikesh, India. J Family Med Prim Care. 2020;9(3):1497-1509.

14. ong $\mathrm{Y}$, Wang HJ, Dong B, Wang Z, Ma J, Agardh A. National Trends in Hemoglobin Concentration and Prevalence of Anemia among Chinese School-Aged Children, 1995-2010. J Pediatr. 2017;183:164-9.

15. I Aref M, O Khalifa HJA-AMJ. Prevalence of Anemia and Associated Factors Among School-Age Children in Al-Haram Zone, Giza Governorate, Egypt. Al-Azhar Med. J. 2019;48(2):165-76.

\section{AUTHORSHIP CONTRIBUTION}

\begin{tabular}{|c|c|}
\hline $\begin{array}{l}\text { Tahira Bibi } \\
\text { Assistant Nursing Instructor, } \\
\text { College of Nursing, Shahdra } \\
\text { Hospital, Lahore Pakistan }\end{array}$ & Principal Author \\
\hline $\begin{array}{l}\text { Nazia Yousef } \\
\text { Research Faculty, Department } \\
\text { of Research, Superior } \\
\text { University Lahore Pakistan }\end{array}$ & Review and Theoretical Framework \\
\hline $\begin{array}{l}\text { Neelam Zia } \\
\text { Faculty of Nursing, Sir Ganga } \\
\text { Ram Hospital, Lahore } \\
\text { Pakistan }\end{array}$ & Data Collection \\
\hline $\begin{array}{l}\text { Uzma Tariq } \\
\text { Biostatistician, Department of } \\
\text { Research, Superior University } \\
\text { Lahore Pakistan }\end{array}$ & Data Analysis \\
\hline
\end{tabular}

